Upper Volta

Robert R. Griffeth (Los Angeles, California): the Dyula of Bobo-Dioulasso and surrounding regions in the nineteenth century.

\title{
Rhodes University, Grahamstown: Institute of Social and Economic Research
}

THE following research projects are being undertaken and written up by members of the Department of African Studies:

The role of the headman in the socio-economic system of the Cape Nguni (Professor W. D. Hammond-Tooke; field-work completed); African middle-class élites (Dr. T. Nyquist; field-work completed); Bantu Christians and their churches (Professor B. A. Pauw; field-work completed); The Bhengu 'Assemblies of God' (Mr. A. A. Dubb; field-work completed); Structural features of the Tembe-Thonga (Mr. W. S. Felgate; fieldwork completed); Religion and witchcraft among the Ndlambe (Mr. F. H. Bigalke).

\section{University of Zambia: Institute for Social Research}

Socral and urban studies undertaken by members of the Institute include the following:

Social responses to economic change in Serenje (Dr. N. Long; his book on this project, Social Change and the Individual, has recently been published by the Institute for Social Research and is reviewed in this issue of Africa, p. 307).

Social organization, traditional and cash economy, and modes of adaptation to the surrounding social milieu of a mixed Shona-Tonga community in the Zambezi Valley (Mr. Lancaster).

A study of the Ila-speaking peoples of Mamwala District, the varying incidence of change in adjacent ecological settings, with special reference to the effects of education and labour migration on village settlement, social and economic organization, and local government (Mr. R. Fielder).

Participation in urban economic activities by an otherwise traditional community in the peri-urban area near Kalulushi; a study of some urban townships in Kitwe (Mrs. Annette Jere).

Leadership patterns in a community development project near Kasama (Mr. M. Simon). Spatial aspects of social change, especially the alterations in crop and land-use patterns, in Serenje District (Mr. D. J. Siddle).

Agricultural geography of the Kafue Basin (Mr. R. M. Phillips).

Royal musicians in Zambia (Mr. I. M. Mapoma).

Population fertility, and the two-way pattern of population exchange between the rural and urban areas; an analysis of the 1963 Census (Dr. P. O. Ohadike).

Economic activities of co-operatives, petty traders, and voluntary associations in Malepole, with data from surveys of households and shop clientele (Miss C. Neil).

\section{Research Material Relating to Zambia}

THE University of Zambia Library is establishing a comprehensive collection of documents and papers relating to Zambia and neighbouring countries. The Institute for Social Research's library has been amalgamated with these materials and its holdings are now being recatalogued. Donations include the Clifford Little collection, consisting primarily of Zambiana, and also that of Dr. H. J. Simons, now Reader in Sociology at the University of Zambia. Mr. Loveday, the Librarian, is undertaking a survey of the country's libraries to determine their scope and locate any special collections, and is preparing a handbook of Zambian libraries. 